\title{
Control of HIV-1 by multiple immunodominant HIV-1-specific CD8+ T cells in HIV-1-infected Japanese individuals
}

\author{
H Murakoshi ${ }^{1 *}$, M Koyanagi $^{1}$, H Gatanaga ${ }^{2}$, T Naruto ${ }^{1}$, S Oka² ${ }^{2}$ M Takiguchi ${ }^{1}$ \\ From AIDS Vaccine 2012 \\ Boston, MA, USA. 9-12 September 2012
}

\section{Background}

Previous studies of the comprehensive analysis of HIV-1specific CTL responses in Caucasian and African cohorts demonstrated the association of the CTL responses to HIV-1 Gag protein with the control of HIV-1 replication. However, such analysis in Asian cohorts has not been reported. In the present study, we performed the comprehensive analysis of $\mathrm{CD} 8^{+} \mathrm{T}$ cell responses against 11-mer overlapping HIV-1 Nef, Gag, and Pol peptides in 401 chronically HIV-1 clade B-infected treatment-naive Japanese individuals.

\section{Methods}

The $\mathrm{CD}^{+} \mathrm{T}$ cell responses to cocktails of the peptides were evaluated by measuring IFN-g-producing $\mathrm{CD} 8^{+} \mathrm{T}$ cells by using ELISPOT assay.

\section{Results}

To clarify CTLs which control HIV-1 infection in this cohort, we statistically analyzed differences of viral load and CD4 counts between responders to each peptide cocktail in each $\mathrm{HLA}^{+}$individuals and non-responders using two-tailed Mann-Whitney's test. We found that several HLA alleles were significantly correlated with low viral load and high CD4 counts in the responses to $5 \mathrm{Nef}$, $10 \mathrm{Gag}$, or 16 Pol cocktails. In these cocktails, we identified 2 Nef, 12 Gag and 7 Pol CTL epitopes restricted by 9 HLA alleles. The breadth of CTL responses to these epitopes was significantly associated with low viral load $\left(\mathrm{p}=1.7 \times 10^{-10}\right)$ and high $\mathrm{CD} 4$ counts $\left(\mathrm{p}=4.1 \times 10^{-13}\right)$. The total magnitude of responses to the epitopes was also

${ }^{1}$ Center for AIDS Research, Kumamoto University, Kumamoto, Japan Full list of author information is available at the end of the article significantly correlated with low viral load $(\mathrm{r}=-0.30$, $\left.\mathrm{p}=1.8 \times 10^{-9}\right)$ and high CD4 counts $\left(\mathrm{r}=0.37, \mathrm{p}=5.0 \times 10^{-14}\right)$.

\section{Conclusion}

These results suggest that the CTL responses to these epitopes play an important role in the control of HIV-1 infection in chronically HIV-1-infected Japanese individuals.

\section{Author details}

${ }^{1}$ Center for AIDS Research, Kumamoto University, Kumamoto, Japan. ${ }^{2}$ AIDS Clinical Center, National Center for Global Health and Medicine, Tokyo, Japan.

Published: 13 September 2012

doi:10.1186/1742-4690-9-S2-P256

Cite this article as: Murakoshi et al:: Control of HIV-1 by multiple immunodominant HIV-1-specific CD8+ T cells in HIV-1-infected Japanese individuals. Retrovirology 2012 9(Suppl 2):P256.

Submit your next manuscript to BioMed Central and take full advantage of:

- Convenient online submission

- Thorough peer review

- No space constraints or color figure charges

- Immediate publication on acceptance

- Inclusion in PubMed, CAS, Scopus and Google Scholar

- Research which is freely available for redistribution 